\title{
Az INF-szerződés haláltusája
}

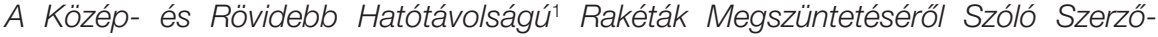
dés (Treaty between the United States of America and the Union of Soviet Socialist Republics on the Elimination of Their Intermediate-Range and Shorter-Range Missiles, vagy más néven Intermediate-Range Nuclear Forces Treaty - INF) már régóta válságban van. Az Egyesült Államok nyilvánosan elöször 2014-ben vádolta meg Oroszországot azzal, hogy megszegi a szerződést. Az elmúlt öt évben a felek több diplomáciai kísérletet is tettek a probléma megoldására, de ezek sorra kudarcba fulladtak. Michael Pompeo külügyminiszter 2018. december 4-én bejelentette, hogy a Trump-adminisztráció 60 napot ad Moszkvának a szerződésszegés tisztázására, ezt követően pedig felmondja az INF-szerződést. Mivel Oroszországnak nem sikerült eloszlatnia Washington aggályait, 2019. február 1-jén a Fehér Ház benyújtotta felmondó nyilatkozatát. Az INFszerződés értelmében, a megállapodás hatálya a felmondás után hat hónappal szünik meg. Ezalatt a hat hónap alatt a felek tehetnek még egy utolsó utáni kísérletet a problémák rendezésére, de a jelenlegi helyzetben és a politikai akarat nyilvánvaló hiányában ugyanakkor valószínübb, hogy Washington és Moszkva hamarosan elkezdi az INF által tiltott fegyverrendszerek kutatását, fejlesztését és korlátozás nélküli hadrendbe állitását.
\end{abstract}

Kulcsszavak: nukleáris fegyverek, INF, NATO, Trump, Oroszország, Egyesült Államok

\section{Péczeli Anna: The Demise of the INF Treaty}

The Treaty between the United States of America and the Union of Soviet Socialist Republics on the Elimination of their Intermediate-range and Shorter-range Missiles, or in other words, the Intermediate-Range Nuclear Forces Treaty (INF Treaty) has been in a crisis for a long time. In 2014, the United States has publicly accused Russia of violating the agreement. Over the past 5 years, the two sides have taken numerous diplomatic attempts to resolve the issue, but all of these attempts failed. On December 4, 2018, Secretary of State Michael Pompeo announced that the Trump Administration gave Moscow 60 days to resolve the compliance problem, otherwise they will withdraw from the INF Treaty. As Russia did not manage to address the concerns of Washington, the White House has officially submitted its withdrawal on February 1, 2019. According to the INF Treaty, the agreement will cease to be in effect six months after the withdrawal. During this timeframe, the two sides may take a last attempt to address their disagreements. However, it is more likely that in the current environment and in the obvious lack of political will, Washington and Moscow will soon start the research, development and unrestricted deployment of the weapons systems which were prohibited by the INF Treaty.

Keywords: nuclear weapons, INF, NATO, Trump, Russia, United States

\footnotetext{
A nemzetközi szakirodalomban nincs egyetértés a különböző kategóriákat illetően, de általában interkontinentális hatótávolságú (vagy hadászati) fegyverrendszerekről beszélünk $5500 \mathrm{~km}$ felett, közepes hatótávolságú fegyverrendszerekről 2400-5500 km között, közepes hatótávolságú fegyverrendszerekről 800-2400 km között és rövid hatótávolságú fegyverrendszerekről $800 \mathrm{~km}$ alatt.
} 


\section{Az INF-szerződés jelentősége}

Amikor 1987 decemberében Ronald Reagan amerikai elnök és Mihail Gorbacsov szovjet pártfőtitkár aláírták az INF-szerződést, az minden szempontból úttörő volt a nukleáris fegyverek korlátozásában. Az úgynevezett kis hidegháború csúcsán Moszkva SS-20 közepes hatótávolságú ballisztikus rakétákat telepített Európába, amelyek három nukleáris töltet hordozására voltak képesek, és hatótávolságuknak köszönhetően egyértelmüen a nyugateurópai hatalmak megfélemlítését célozták. Válaszként a NATO-szövetségesek 1979-ben döntést hoztak 108 közepes hatótávolságú Pershing II ballisztikus rakéta, és 464 szárazföldi indítású robotrepülőgép (BMG-109G) európai telepítéséről. A rakéták közelsége miatt ezek a fegyverek 8-10 perc alatt elérhették volna Moszkvát, és a szovjet vezetés szemében egy meglepetésszerü első csapás kulcselemei voltak. ${ }^{2}$ Ezek a rakéták egyik fél biztonságát sem növelték - mindkét oldal tartott attól, hogy a másik fél meglepetésszerü nukleáris csapást fog indítani ezekkel a fegyverekkel, ráadásul a véletlenszerü kilövések és a technikai hibák kockázata is jelentősen megnőtt. Ez a kölcsönös fenyegetettségérzet elég volt ahhoz, hogy az 1986-os reykjavíki csúcstalálkozón az amerikai elnök és szovjet pártfötitkár ambiciózus leszerelési tervekkel üljön le az asztalhoz. Gorbacsov valamennyi ballisztikus rakétát be akart tiltani, Reagan ugyanakkor nem volt hajlandó az úgynevezett Csillagháborús rakétavédelmi terv korlátozására (még annak ellenére sem, hogy ez a program 1986-ban még csak elméleti síkon létezett). ${ }^{3} \mathrm{Az}$ INF-szerződés végül egyfajta kompromisszum volt a felek között, ami a legveszélyesebb fegyverek kivonásával jelentősen lecsökkentette a nukleáris háború veszélyét Európában, korlátokat szabott a két szuperhatalom fegyverkezési versenyének, és hozzájárult a hidegháború végéhez.

Az INF-szerződés ${ }^{4}$ kimondta, hogy az Egyesült Államoknak és a Szovjetuniónak le kell szerelnie összes 500 és 5500 km közötti szárazföldi indítású ballisztikus rakétáját és robotrepülőgépét ${ }^{5}$ (ez magában foglalta a nukleáris és a hagyományos töltettel felszerelt rakétákat is). Az INF-szerződés két szempontból volt mérföldkő az amerikai-szovjet fegyverzetkorlátozás történetében: egyrészt ez volt az első megállapodás, ami ténylegesen csökkentette a két fél nukleáris arzenálját, és maradéktalanul felszámolt egy teljes fegyverkategóriát; másrészt pedig ez volt az első olyan megállapodás, amelynek a verifikációs mechanizmusa magában foglalta a helyszíni ellenőrzéseket. A fejlett ellenőrzési rendszerének és a sikeres eredményeinek köszönhetően az INF-szerződés négy évvel később modellként szolgált a stratégiai atomfegyverek korlátozását célzó START-szerződésnek is. Az INF-szerződésnek köszönhetően Washington és Moszkva összesen 2692 közép- és kö-

Evgeny Buzhinsky: Does the INF Treaty Have a Future? Security Index: A Russian Journal on International Security, 20. évf., 2014/2, 89-93. o.

David W. Kearn: Russian Missiles and the Growing Security Crisis in Europe, [online], 2014. 08. 28. Forrás: European Leadership Network [2019. 02. 02.]

3 David E. SANGer - William J. BroAd: U.S. to Tell Russia It Is Leaving Landmark I.N.F. Treaty, [online], 2018. 10. 19. Forrás: The New York Times [2019. 02. 02.]

4 INF Treaty: Treaty Between The United States Of America And The Union Of Soviet Socialist Republics On The Elimination Of Their Intermediate-Range And Shorter-Range Missiles (INF Treaty), [online], 1987. 12. 08. Forrás: State.gov [2019. 02. 02.]

5 Az angol „cruise missile” kifejezést, a magyar szaknyelv robotrepülőgépnek fordítja, de a köznyelvben gyakran használják - hibásan - a cirkáló rakéta kifejezést is ennek a fegyverkategóriának a megnevezésére. 
zepes hatótávolságú rakétát semmisített meg 1991 júniusára. A Szovjetunió megszabadult az SS-20, az SS-4, az SS-5, az SS-12 és az SS-23 ballisztikus rakétáitól, illetve az SSC-X-4 robotrepülőgépeitől (összesen 1846 rakétától). Az amerikai oldal megsemmisítette az öszszes Pershing II és Pershing IB ballisztikus rakétáját, illetve valamennyi szárazföldi indítású robotrepülőgépét és kilövőállását (összesen 846 rakéta). ${ }^{6}$

A Szovjetunió és az Egyesült Államok, továbbá az egész NATO szövetségi rendszer szempontjából az INF-szerződés megkötése számos előnnyel járt. Egyrészt stabilitást hozott a két hidegháborús szuperhatalom viszonyrendszerébe, mivel mindkét felet önkorlátozásra kényszerítette, illetve bizonyos kiszámíthatóságot teremtett. Csökkentette továbbá a katonai kiadásokat, és a nukleáris arzenálok pusztító potenciáljának korlátozása révén csökkentette egy esetleges háború költségeit és a várható áldozatok számát is. Emellett a legveszélyesebb fegyverkategóriában sosem látott átláthatóságot hozott, és a verifikációs mechanizmusoknak köszönhetően olyan ellenőrzési módszereket írt elő, amelyekkel a szerződésszegéseket a felek korán tudták észlelni. Az INF-szerződés rendelkezett továbbá olyan technikai és diplomáciai csatornák létesítéséről, amelyeken keresztül a problémás kérdéseket a felek békés módon meg tudták vitatni. E tekintetben a legfontosabb csatorna a Speciális Verifikációs Bizottság (Special Verification Commission - SVC) lett. A NATO szempontjából további előnyt jelentett, hogy az INF-szerződés megkötése véget vetett a rendkívül gyors és átláthatatlan szovjet rakétafejlesztéseknek. A Szovjetunió számára pedig a legnagyobb nyereség az volt, hogy az INF enyhítette a moszkvai vezetés meglepetésszerü elsőcsapással kapcsolatos aggodalmait.

\section{Az INF-szerződés betartásával kapcsolatos aggodalmak}

Az Egyesült Államok 2014-es vádjai és a szerződés 2019-es felmondása nem elszigetelt esetek voltak, hanem az INF-szerződés régóta zajló erodálásának utolsó lépcsőfokai. Moszkva legnagyobb problémája a szerződéssel az, hogy az csak az Egyesült Államokat és Oroszországot köti, miközben az Oroszországot körülvevő államokat (elsősorban Kínát) nem korlátozza. Míg ugyanis az 1980-as évek végén az Egyesült Államoknak és a Szovjetuniónak egyértelmű monopóliuma volt a közép-hatótávolságú rakétafegyverek terén, addig napjainkra Észak-Korea, India, Irán, Izrael, Kína, Pakisztán és Szaúd-Arábia is rendelkezik ilyen hatótávolságú rakétákkal. ${ }^{7}$ Oroszország nyíltan a 2000-es évek elejétől bírálta a szerződést, és maga Vlagyimir Putyin is többször megkérdőjelezte, hogy az INF továbbra is Moszkva érdekeit szolgálja-e. ${ }^{8}$ 2007-ben Szergej Ivanov orosz védelmi miniszter a „legnagyobb hibának” nevezte, hogy Oroszország lemondott egy teljes fegyverrendszerről, és az INF-szerződés felmondása mellett érvelt. ${ }^{9}$

Az elmúlt 15 évben Oroszország kapcsán számos különböző fegyverrendszer gyanút keltett a nyugati hatalmakban. Amíg az Egyesült Államok meg nem nevezte pontosan,

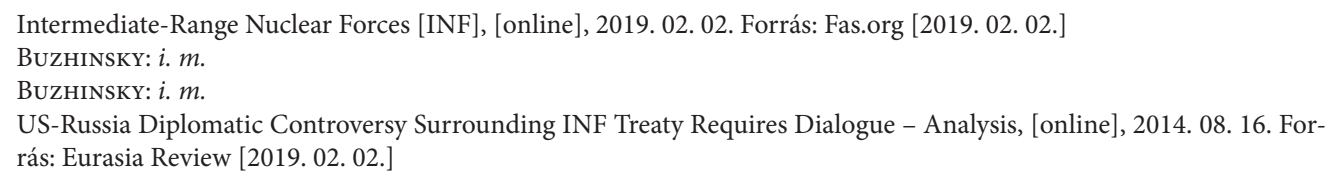


hogy melyik rakéta képezte a hivatalos amerikai vádak alapját, több lehetőség is játékban volt. Az első a több robbanófej hordozására is alkalmas RS-26 Rubezs (NATO elnevezésben SS-27 Mod 2) interkontinentális ballisztikus rakéta (Intercontinental Ballistic Missile - ICBM), amelyet Oroszország az első sikeres interkontinentális tesztkilövést követően háromszor is közép-hatótávolságon tesztelt, azt sejtetve, hogy az RS-26 rendszer elsődleges feladata a NATO-tagállamok megfélemlítése lesz. ${ }^{10}$ A második vitatható rendszer az R-500 (Iszkander-K) robotrepülőgép volt. Az Iszkander-K rendszer hivatalos hatótávolsága $500 \mathrm{~km}$, Oroszország azonban vélhetően több sikeres tesztkilövést is végrehajtott $500 \mathrm{~km}$ hatótávolság felett, ami egyértelmüen az INF megszegését jelentette. Szakértők véleménye szerint ezt a képességet Oroszország elsősorban a NATO európai rakétavédelmi rendszerével szemben telepítette. ${ }^{11}$ A harmadik probléma egy tengeri indítású robotrepülőgép (Sea-Launched Cruise Missile - SLCM), az SS-N-21 szabálytalan tesztelése volt. Az INF-szerződés ugyan nem korlátozza a közép-hatótávolságú SLCM-rendszerek fejlesztését és birtoklását, ezek tesztelése viszont csak olyan „rögzített szárazföldi telepítésü indító-berendezésekből történhet, melyeknek kizárólagos célja a tesztelés, és melyek egyértelmüen elkülöníthetőek a GLCM indító-berendezésektől”. ${ }^{12}$ Oroszország vélhetően nem minden esetben felelt meg ennek az elvárásnak, ami az INF-szerződés technikai megsértését jelentené.

Az iménti felsorolásból is jól látszik, hogy Moszkva már régóta feszegeti az INFszerződés határait. Ma már azonban tudjuk, hogy a hivatalos amerikai vádak alapját nem ezek a technikai szabálysértések képezték, hanem egy teljesen új fejlesztésü szárazföldi indítású robotrepülőgép (Ground-Launched Cruise Missile - GLCM), amelynek hatótávolsága egyértelmüen az INF-szerződés hatálya alá esik. A rendszer orosz elnevezése Novator 9M729, NATO elnevezése pedig SSC-8. Az új rendszerrel kapcsolatos hírek és az INF-szerződés válsága 2014-ben kerültek nyilvánosságra, amikor az Egyesült Államok Külügyminisztériuma hivatalosan is aggodalmát fejezte ki az INF-szerződés Oroszország általi megsértésével kapcsolatban. Az amerikai külügyminisztérium minden évben elkészíti helyzetértékelését (Compliance Report) a fegyverzetkorlátozási megállapodások betartásáról. Ezt a jelentést a Kongresszus számára készíti, hogy szerződésszegés esetén a törvényhozás dönthessen a megfelelő bűntető mechanizmusokól. A külügyminisztérium 2014. július 31-én kiadott jelentése szerint „az Orosz Föderáció megszegi az INF-szerződésben foglalt kötelezettségeit arra vonatkozóan, hogy nem birtokol, fejleszt, vagy tesztel 500 és $5500 \mathrm{~km}$ hatótávolság közötti szárazföldi indítású robotrepülögépeket (GLCM), illetve nem birtokol és fejleszt ezekhez szükséges indítóberendezéseket". ${ }^{13}$

10 Jeffrey Lewis: Russia and the INF Treaty, [online], 2014. 04. 28. Forrás: Arms Control Wonk [2019. 02. 02.] Amy F. Woolf: Russian Compliance with the Intermediate Range Nuclear Forces (INF) Treaty: Background and Issues for Congress, [online], 2015. 10. 13. Forrás: Congressional Research Service [2019. 02. 02.]

11 Alexander Tıмosнiк: New Russian missile R-500 to destroy any US defense system, [online], 2007. 05. 30. Forrás: Pravda [2019. 02.02.]

Douglas BARrie - Henry Boyd: Russian Cruise Missile Goes Off-Range, [online], 2014. 07. 21. Forrás: IISS Military Balance Blog [2019. 02. 02.]

12 INF Treaty: $i . m$.

13 U.S. Department of State: Adherence to and Compliance With Arms Control, Nonproliferation, and Disarmament Agreements and Commitments, [online], 2014. 07.31., 8. o. Forrás: State.gov [2019. 02. 02.] 
$\mathrm{Az}$ amerikai jelentésböl kiderült, hogy egy GLCM-rendszer jelentette a problémát, a rakéta pontos megnevezését és az ezzel kapcsolatos részleteket azonban csak 2018 januárjában hozta nyilvánosságra Washington. A hírszerzési információk (illetve az azok begyűjtését segítő módszerek) védelmére hivatkozva az Obama-adminisztráció sem a NATO szövetségesekkel, sem pedig Oroszországgal nem osztotta meg az amerikai vádakat alátámasztó bizonyítékokat, ami politikai szempontból Oroszországnak kedvezett. Az elmúlt pár hónapban nyilvánosságra hozott adatokból azonban ma már tudjuk, hogy a kérdéses Novator 9M729 GLCM fejlesztését Oroszország a 2000-es évek közepén kezdte, és először 2008-ban hajtott végre tesztkilövést. A rendszert 2015-re már mobil és rögzített kilövőállásokból is tesztelte Moszkva (jóval az INF-szerződés $500 \mathrm{~km}$-es határértéke felett), majd 2016 decemberében megkezdte a Novator 9M729 GLCM hadrendbe állítását. ${ }^{14}$

Oroszország stratégiája kezdettől a tagadásra épült, és a mai napig nem ismerte el, hogy megsértette volna az INF-szerződést. Akárcsak az Egyesült Államok, Oroszország is több tekintetben aggályosnak találta a másik fél rakétafejlesztéseit, és a 2000-es évek közepe óta számos alkalommal nyíltan megvádolta Washingtont az INF-szerződés megszegésével. Az orosz aggályok alapvetően három rendszer köré épülnek: „bizonyos amerikai ballisztikus célrakéták, [...] felfegyverzett pilóta nélküli repülőgépek, [...] és az Aegis Szárazföldi Telepítésű Rakétavédelmi Rendszer által, mely képes Tomahawk robotrepülőgépek indítására is". ${ }^{15} \mathrm{Az}$ orosz vádakra adott válaszként Brian P. McKeon, az Obama-adminisztráció helyettes védelmi államtitkára elmondta, hogy a célrakéták kizárólagos célja a rakétavédelmi rendszerekkel kapcsolatos kutatás és fejlesztés, nem pedig a támadó rakéták fejlesztése. A második vádat illetően McKeon hangsúlyozta, hogy a fedélzeti rakétákkal felfegyverzett pilóta nélküli repülőeszközök visszahívható és többször felhasználható rendszerek, ezért nem esnek az INF hatálya alá. Végül biztosította az orosz felet arról is, hogy az Aegis szárazföldi telepítésü rakétavédelmi rendszer SM-3 elfogórakétáinak Mk-41-es függőleges indítóberendezései nem egyeznek meg a tengeri indítású Tomahawk robotrepülőgépekhez használt indítóberendezésekkel. ${ }^{16} \mathrm{Ez}$ utóbbi állítás csak részben igaz, és az ezzel kapcsolatos orosz aggodalmak némiképp helytállóak, hiszen maga a haditengerészet weblapja ismeri el, hogy az Mk-41 indítóberendezés több célú, és az SM-rendszer mellett Tomahawk robotrepülögépek kilövésére is alkalmazható. ${ }^{17} \mathrm{Az}$ egyetlen lényegi különbség, hogy az Aegis-rendszerben eltérő elektronikát és szoftvert használnak - ezen ugyanakkor viszonylag könnyen és olcsón lehet változtatni. ${ }^{18}$

Az INF-szerződéssel kapcsolatban tehát mindkét oldalnak vannak jogos félelmei, fontos ugyanakkor hangsúlyozni, hogy a nyilvánosságra hozott információk alapján tényleges szerződésszegést csak Moszkva követett el.

\footnotetext{
Woolf: i. m.

15 Brian P. McKeon: Statement of Honorable Brian P. McKeon, Principal Deputy Under Secretary of Defense for Policy before the House Committee on Armed Sercives, Subcommittee on Strategic Forces and Committee on Foreign Affairs, Subcommittee on Terrorism, Nonproliferation, and Trade, [online], 2014. 12. 10. Forrás: House.gov [2019. 02. 02.]

16 Uo.

17 Department of the Navy: United States Navy Fact File MK 41-VLS, [online], 2016. 05. 09. Forrás: Navy.mil [2019. 02. 02.]

18 Ulrich KüHn - Anna PÉczelr: Russia, NATO, and the INF Treaty, [online], Strategic Studies Quarterly, 11. évf., 2017/1, 66-99. o.
} 


\section{Kinek a felelőssége az INF széthullása?}

Miként az előző fejezet bemutatta, az INF-szerződés problémái visszanyúlnak a 2000-es évek elejéig. Miután Oroszország 2008-ban végrehajtotta a Novator 9M729 GLCM első tesztkilövését, az Egyesült Államok hat évig várt azzal, hogy nyilvánosan is megvádolja Moszkvát. Ennek két fó oka volt: egyrészt az Obama-adminisztráció bízott abban, hogy a kérdést sikerülhet diplomáciai úton, a színfalak mögött megoldani; másrészt nem akarták felbőszíteni Moszkvát az Új START-szerződés tárgyalási folyamatának lezárása előtt.

Ezalatt a hat év alatt számos diplomáciai egyeztetésre került sor, Moszkva azonban kategorikusan tagadta a GLCM létezését, s az amerikai erőfeszítések rendre zsákutcába futottak. ${ }^{19}$ Fontos hangsúlyozni, hogy az Obama-adminisztráció egyértelmüen eltökélt volt az INF-szerződés megmentése mellett. Stratégiailag azonban komoly hibát követett el azzal, hogy sem Moszkvával, sem a szövetségesekkel nem osztotta meg, hogy milyen bizonyítéka van az orosz szerződésszegésről (a szövetségesekkel kezdetben mindössze a rakétarendszer nevét osztotta meg). Miután a Bush-adminisztráció és az iraki fiaskó eljátszotta Washington hitelét a „titkos tömegpusztító fegyver-programokkal” kapcsolatos állítások terén, az európai szövetségesek vagy kétkedve, vagy pedig érdektelen közömbösséggel fogadták az amerikai vádakat, arra hivatkozva, hogy az INF-szerződésszegés amerikai-orosz probléma. Ez nagyon kényelmes pozíciót teremtett Moszkva számára, hiszen bizonyítékok híján továbbra is tagadhatta az amerikai vádakat, nem kellett túl komoly következményekkel szembenéznie, és közben hangoztathatta saját aggályaikat az amerikai szerződésszegéssel kapcsolatban. Válaszként az Obama-adminisztráció számos szankciót helyezett hatályba, részben az INF-szerződésre, részben pedig az ukrajnai orosz agresszióra hivatkozva. Ezek a lépések azonban nem hoztak komolyabb áttörést a kérdésben.

A Trump-adminisztráció merőben más hozzáállással közelítette meg az INF-szerződés körüli problémákat. Trump és közeli tanácsadói jóval szkeptikusabbak a fegyverzetkorlátozási szerződések előnyeit illetően, s az iráni nukleáris szerződésből való kihátrálással egyértelmüen jelezték, hogy nem fognak hezitálni az INF-szerződés felrúgásával sem, ha Moszkva nem függeszti fel a Novator 9M729 GLCM fejlesztését és hadrendbe állítását. A szövetségesek számára viszont problémát jelentett, hogy az amerikai kormány részéről némiképp ellentmondó üzenetek érkeztek hozzájuk. Míg a James Mattis által vezetett Védelmi Minisztérium igyekezett diplomáciai megoldást találni a kérdés megoldására, és 2018 októberében a legfontosabb európai szövetségeseket arról biztosította, hogy a washingtoni adminisztráció mindent megtesz a szerződés megmentéséért, addig másnap Donald Trump, teljesen szokatlan módon, egy kampány eseményen bejelentette az Egyesült Államok felmondási szándékát. ${ }^{20}$ Ennek egyenes következménye volt, hogy Michael Pompeo külügyminiszter 2018 decemberében a NATO brüsszeli külügyminiszteri találkozóján 60 napos határidőt adott Moszkvának, hogy beszüntesse a szerződésszegést, különben Washington hivatalosan is felmondja a megállapodást. ${ }^{21}$ Miután az amerikai

\footnotetext{
A szerző személyes beszélgetése a Pentagon több munkatársával.

SANGER-BROAD: $i . m$.

21 Michael R. Pompeo: Remarks by Secretary of State at NATO Headquarters, December 2018, [online], 2018.12 .04$. Forrás: State.gov [2019. 02.02.]
} 
vezetés nem találta kielégítőnek az orosz lépéseket, 2019. február 1-jén bejelentette, hogy felmondja az INF-szerződést. Ez a gyakorlatban azt jelenti, hogy hat hónapon belül az INFszerződés megszünik, és mindkét fél korlátozás nélkül telepíthet szárazföldi indítású közép-hatótávolságú rakétarendszereket.

Az Obama-adminisztráció alapvető problémája az volt, hogy mindössze a politikai és gazdasági nyomásgyakorlás eszközeivel éltek, s ezek az európai szövetségesek támogatása nélkül nem bizonyultak elégnek. Ha Washington rögtön megosztotta volna a bizonyítékait az európai szövetségesekkel, akkor egy koordinált nyomásgyakorlással talán jobb eredményeket lehetett volna elérni; vagy elhitethette volna az orosz vezetéssel, hogy hajlandó tényleges katonai lépéseket tenni, hogy Moszkva ne jusson valódi előnyökhöz az új rakétarendszerrel. Mivel az INF-szerződés nem tiltja a kutatás-fejlesztést, az Obamakormány - a második lehetőséggel összefüggésben - elkészíthetett volna például egy egyszerű megvalósíthatósági tanulmányt a Pershing III ballisztikus rakéták fejlesztéséről, csakhogy Moszkva jobban átgondolja, hogy megéri-e az új GLCM telepítése, és komolyabban vegye az amerikaiak által hangoztatott vádakat. Ismerve Oroszország reakcióját az európai ballisztikus rakétavédelmi rendszerről, ennek a rendszernek a bővítése is kemény üzenet lehetett volna Putyin elnök felé. Ezek hiányában azonban az Obama-kormány lépései nem hoztak eredményt.

Ezzel szemben, a Trump-adminisztráció problémája épp ellentétes volt. Sem az elnök, sem pedig John Bolton nemzetbiztonsági tanácsadó nem volt teljesen eltökélt a szerződés megmentése mellett, így a diplomáciai és gazdasági nyomásgyakorlás eszközei nem voltak megfelelően kihasználva. ${ }^{22}$ A Trump-adminisztráció INF-szerződéssel szembeni ellenérzései ugyanis nem csak abból erednek, hogy Oroszország éveken át nyíltan és komolyabb következmények nélkül megszeghette a szerződést. Legalább ennyire abból az igényből is, hogy az Egyesült Államok számára megnyíljon a közép-hatótávolságú rakétafegyverek szárazföldi telepítésének esélye a csendes-óceáni térségben, ahol elképzelhető, hogy Kína egyre növekvő ballisztikus rakéta és robotrepülőgép képességei miatt Washington a jövőben Japán, vagy Guam-szigetén szárazföldi telepítésére fog szorulni a katonai erőegyensúly fenntartása érdekében (a legkomolyabb aggodalmat a Dong-Feng-15, -16, -21, -26 típusú eszközök okozzák).

A Trump-kormány számára komoly diplomáciai lehetőség nyílt, amikor 13 év után újra összehívták a Speciális Verifikációs Bizottságot az INF-szerződésszegés tisztázására. Azok, akik ismerik a kérdés technikai részleteit állítják, hogy megfelelő politikai akarat mellett mind az orosz, mind az amerikai aggodalmakat kielégítően rendezni lehetett volna. Az SVC-találkozó azonban teljes kudarc volt, és a felek a vádak megismétlésén kívül nem jutottak sehova. ${ }^{23} \mathrm{~A}$ Trump-kormány tehát a diplomáciai megoldáskeresés terén nem teljesített túl jól, míg a katonai lépéseket túlhangsúlyozta. A 2018 első felében kiadott új nukleáris stratégiájában a Fehér Ház előirányozta két kis hatóerejü atomfegyver újbóli hadrendbe állítását. A lépés kapcsán az elmúlt években megnövekedett orosz agresszióra és Moszkva nukleáris eszkalációs stratégiájára hivatkoztak, amely arra az elméletre épül,

\footnotetext{
22 David E. SAnger: U.S. Suspends Nuclear Arms Control Treaty With Russia, [online], 2019. 02. 01. Forrás: The New York Times [2019. 02.02.]

23 A szerző személyes beszélgetése az SVC találkozó egyik résztvevőjével.
} 
hogy Oroszország hajlandó egy hagyományos fegyverekkel vívott konfliktus korai szakaszában atomfegyverekhez nyúlni annak érdekében, hogy gátat szabjon a további eszkalációnak és számára kedvező feltételekkel zárja le az összecsapást. ${ }^{24} 2018$ őszére a Fehér Ház gyakorlatilag eldöntötte, hogy az INF-szerződésnek vége, így a legfőbb célja az volt, hogy a felelősséget egyértelmüen Moszkvára terelje. Ennek érdekében a Fehér Ház végre intenzív információ megosztásba kezdett az új orosz GLCM-ről, ez viszont már túl későn történt ahhoz, hogy az európaiak meg tudják menteni az INF-szerződést.

Bizonyos szempontból az európai szövetségesek is felelösek az INF-szerződés bukásáért. Mert bár igaz, hogy az Egyesült Âllamok csak minimális információt bocsátott rendelkezésükre az orosz szerződésszegésről, de a majdnem négy évig tartó hallgatásuk egyértelműen nem segített a szerződés megmentésében. Sokatmondó a Monterey-i James Martin Center for Nonproliferation Studies kutatóintézet 2015-ös terepkutatása, amely az úgynevezett keleti frontvonalon lévő NATO-tagállamok meglátogatása után arra a következtetésre jutott, hogy a legtöbb európai államnak nem volt különösebb véleménye az INF-szerződés problémáiról, a külügyminisztériumok és védelmi minisztériumok munkatársai nem igazán voltak tisztában az INF jelentőségével, és semmilyen konkrét javaslatuk nem volt arra vonatkozóan, hogy hogyan kellene megmenteni a megállapodást. ${ }^{25}$

$\mathrm{Az}$ európaiak tehát túl későn ébredtek, és annak ellenére, hogy az INF széthullása és a szárazföldi indítású közép-hatótávolságú fegyverek visszatérése az orosz arzenálba elsősorban az ő biztonságukat fenyegetné, mégsem tettek gyakorlatilag semmit az INF megmentéséért. Az oroszokkal folytatott bilaterális találkozókon a NATO európai szövetségesei nem hozták szóba az INF kérdését, a közös elítélő nyilatkozatokon túl semmilyen koordinált diplomáciai nyomásgyakorlásra nem került sor, kimondottan az INF-szerződés miatt nem léptettek hatályba gazdasági szankciókat, és nem volt komolyabb politikai vita az INF megszegésének jelentőségéről sem. Egyedül a német parlamentben voltak meghallgatások az INF-szerződés kérdéséről, és Angela Merkel volt az egyetlen európai államfö, aki egyáltalán felhozta az ügyet a Putyin elnökkel való bilaterális találkozóján. Minderre azonban csak 2018-ban került sor, ami már túl késő volt az események visszafordításához. Az európaiakról az is rendkívül furcsa képet festett, hogy az amerikai felmondással kapcsolatos bejelentés komolyabb európai kritikákba ütközött, mint maga az orosz szerződésszegés. Donald Trump októberi beszédét a legtöbb nagy európai ország harsány reakciókkal fogadta, és a szerződés megmentésére szólították fel. Ez egyrészt végre komolyabb európai diplomáciai összefogást indukált az INF megmentése mellett, másrészt azonban annak rossz visszhangja volt Washingtonban, hogy az európaiak a Fehér Házat bírálják a szerződés tényleges felrúgója helyett. ${ }^{26}$ Amikor Pompeo bejelentette a 60 napos határidőt, a NATO közös nyilatkozatban és egyhangúlag próbálta Oroszországot felszólítani az új GLCM felszámolására és a szerződés rendelkezéseinek betartására, azonban ez sem hozta meg a remélt eredményt.

24 U.S. Department of Defense: Nuclear Posture Review, [online], 2018. 02. 28. Forrás: Dod.defense.gov [2019. 02. 02.]

25 Miles A. Pomper - Egle Murauskaite - Nikolai N. Sokov - Jessica C. Varnum: Ensuring Deterrence against Russia: The View from NATO’s Front-Line States, [online], 2015. 12. 01. Forrás: Nonproliferation.org [2019. 02. 02.]

26 Steven PIfER: RIP INF: The End of a Landmark Treaty, [online], 2018. 10. 29. Forrás: The National Interest [2019. 02. 02.] 
Habár mind Washington, mind a NATO szövetségesek tehettek volna többet az INFszerződés megmentéséért, az elsődleges felelősség mégis Moszkvát terheli az INF bukásáért. Oroszországnak jól jött, hogy a bizonyítékokat Washington sokáig nem hozta nyilvánosságra, így azzal tudott védekezni, hogy tagadta a Fehér Ház állításait, illetve nem adott megfelelő választ arra hivatkozva, hogy nem tudja Washington milyen fegyverekről beszél. Eközben pedig arra emlékeztette a nemzetközi közösséget, hogy az Egyesült Államok az, aki megszegi az INF-szerződést. Ezt a stratégiát némiképp árnyalta Donald Trump 2018. októberi bejelentése az amerikai felmondási szándékról. Amikor egyértelművé vált Moszkva számára, hogy a washingtoni vezetés elkötelezte magát az INF-ből való kilépés mellett, Oroszország több diplomáciai gesztust tett a szerződés megmentésére, hogy optikailag javítsa pozícióját. Moszkva egyrészt konzultatív találkozót kezdeményezett 2019. január közepére Genfben, másrészt pedig meghívta az Egyesült Államokat és nemzetközi megfigyelőket a kérdéses GLCM első nyilvános bemutatójára. A genfi találkozót követően az orosz fél nyíltan arról panaszkodott, hogy az amerikaiak nem voltak hajlandóak az orosz aggodalmak eloszlatására és az álláspontok közelítésére. ${ }^{27}$ A Novator 9M729 GLCM bemutatóján pedig (amelyre az amerikaiak el sem mentek) Moszkva azt próbálta bizonygatni, hogy az új rakéta nem minősül szerződésszegésnek, és csupán egy korábbi modell, az INF-kompatibilis 9M728 GLCM módosított változata. A Kreml állítása szerint az új rakéta kulcselemei teljesen megegyeznek a korábbi modellével, amelynek hatótávolsága 490 km, míg ennek az új GLCM-nek a hatótávolsága $480 \mathrm{~km}$, ami maximálisan megfelel az INF rendelkezéseinek. ${ }^{28}$ Moszkva (meglehetősen késői és átlátszó) diplomáciai erőfeszítéseinek ellenére az Egyesült Államok 2019. február 1-jén benyújtotta kilépési nyilatkozatát, és valószínű, hogy a Putyin-kormány a következő hat hónapban nem fogja az immár hadrendbe állított rakétáit felszámolni, ennek hiányában pedig a szerződés halálra van ítélve.

\section{Hogyan tovább az INF-szerződés bukása után?}

A Novator 9M729 robotrepülőgép jelenlegi telepítését tekintve, a rendszer elsősorban az európai biztonsági architektúrát érinti. Fontos azonban hangsúlyozni, hogy az új GLCM nem változtatta meg a katonai egyensúlyt Európában. A hidegháború végével és a közepes és közép-hatótávolságú rakéták kivonása ellenére sem szünt meg a nukleáris fenyegetés Európa számára. Moszkva, ha akarja, stratégiai atomfegyvereit kisebb hatótávolságon is tudja használni, azaz a nyugat-európai fővárosok sosem tủntek el a célkeresztből. Ennek ellenére, az orosz stratégiai atomfegyverek elsődleges célja az Egyesült Államokkal való kölcsönös fenyegetés fenntartása. Az új GLCM viszont korlátozott hatótávolsága miatt egyértelmű politikai üzenetet hordoz az európai államoknak, és bizonyos szempontból legfontosabb célja az amerikaiak elkötelezettségének tesztelése volt az európai szövetségesek védelme iránt. A NATO belső kohéziójának gyengítése és az európaiakkal szembeni orosz

27 European nuclear powers must intervene in INF Treaty situation, expert says, [online], 2019. 02. 01. Forrás: Tass.com [2019.02.02.]

28 Neil MacFarquhar: Russia Shows Off New Cruise Missile and Says It Abides by Landmark Treaty, [online], 2019.01. 23. Forrás: The New York Times [2019. 02. 02.] 
zsaroló potenciál növelése az európaiak amerikai stratégiai nukleáris elrettentésről való lekapcsolását szolgálják.

A jelenlegi helyzetnek rövid távon egyértelműen Oroszország a nyertese, mivel ezek után nyíltan és korlátok nélkül telepítheti új rakétarendszerét. Hosszú távon azonban nem biztos, hogy Moszkva jól fog járni az INF-szerződés aláaknázásával. Mind Oroszország, mind pedig az Egyesült Államok nagyon szeretné Kínát bevonni a közép-hatótávolságú fegyverek korlátozásába, Peking azonban ez idáig nem mutatott semmilyen hajlandóságot ezeknek a rendszereknek a csökkentésére vagy felszámolására, és viharos politikai kapcsolata a Trump-adminisztrációval nem kecsegtet túl sok ígérettel a jövőre nézve. Oroszország számára az 1990-es évek óta egyre nyilvánvalóbb a hagyományos fegyverek terén meglévő hátránya, amit a nukleáris arzenálja állandó modernizációjával, és a hagyományos, illetve a nukleáris fegyverek közötti választóvonal tudatos elhomályosításával próbál ellensúlyozni. Az INF-szerződés bukása ennek a folyamatnak az egyik tünete volt. Hosszú távon azonban továbbra is egyértelmü, hogy ha Washington és Moszkva újra fegyverkezési versenybe kezd, az Egyesült Államok ismét felül fog kerekedni, pusztán jobb gazdasági képességeinek köszönhetően. Az amerikai fél a következő 30 évben már így is 1300 milliárd dollárt tervez nukleáris modernizációra költeni, és bár a jelenlegi nehéz költségvetési környezetben nem kívánja ezt lényegesen megemelni, de az biztos, hogy Oroszországnál még így is több mozgástere van a katonai kiadások emelésére.

Mivel az Egyesült Államok 1987 óta teljesen felfüggesztette az INF-fegyverek fejlesztését, nagyjából 7-8 évre lenne szüksége ahhoz, hogy egy új szárazföldi indítású ballisztikus rakétát telepítsen Európába. Ez több szempontból sem valószínü forgatókönyv: egyrészt a NATO-szövetségesek jelezték, hogy nem kívánnak új „eurorakétáknak” otthont adni; másrészt ez rendkívül drága lenne a már jelenleg is szoros költségvetési körülmények között; harmadrészt pedig számos jobb katonai opciója is van Washingtonnak az új orosz GLCM ellensúlyozására. A már említett kis hatóerejü atomfegyverek visszahozatala az amerikai arzenálba (az atom-tengeralattjárók által hordozott Trident ballisztikus rakétáknak egy alacsony hatóerejű verziója, és egy új tengeri indítású robotrepülőgép fejlesztése), a Trump-adminisztráció által 2019 januárjában előterjesztett rakétavédelmi fejlesztések, az új légi indítású robotrepülőgép (LRSO), illetve a B61-12-es „manőverezhető” szabadesésű atombomba érkezése Európába mindenképp alkalmasak arra, hogy egyensúlyban tartsák a NATO-orosz nukleáris képességeket. Washington számára azonban fontos lecke, hogy a szövetségesekkel való jobb információmegosztás kulcsfontosságú lehet a jövőbeli hasonló esetekben. A Trump-adminisztráció kapcsolata Európával több szempontból is ingatag, és az INF felrúgása után a Fehér Háznak valahogy újra összhangba kell kerülnie európai szövetségeseivel. A robotrepülőgépekkel szembeni védelemben a NATO-nak még van hova fejlődnie, és az európai rakétavédelem telepítésében is szükség van az együttmüködésre. Emellett, ha a Fehér Ház nagyobb szerepvállalást vár el az európaiaktól a B-2-es és a B-52-es stratégiai bombázók rotációjának elősegítésében, a nukleáris hadgyakorlatok támogatásában, illetve az új F-35-ös vadászgépek vásárlásában, akkor szintén szükség lesz a politikai kapcsolatok normalizációjára.

Az európai hatalmak egy része az amerikai-európai elhidegülést egyfajta lehetőségként látja az európai stratégiai önállóság megteremtésére. Amennyiben a Trump-kormánnyal 
nem rendeződnek a vitás kérdések, lehet, hogy Németország és Franciaország ennek a folyamatnak az élére fog állni, ami akár életre hívhat egy európai-orosz párbeszédet is, Washington kihagyásával. Habár Moszkva ennek a forgatókönyvnek rendkívül örülne, ehhez azért több rendkívül szoros katonai együttmüködésnek kellene zsákutcába futnia a Fehér Ház és az európaiak között.

Az INF-szerződés felmondásának talán az egyik legaggasztóbb vetülete a fegyverzetkorlátozás rendszerének és az európai biztonsági architektúrának a rendkívül aggasztó állapota. Miután a Bush-adminisztráció 2002-ben felmondta a rakétavédelmi rendszerek korlátozását célzó $\mathrm{ABM}$-szerződést, Washington és Moszkva felfüggesztette a stratégiai atomfegyverekre vonatkozó SORT-megállapodást (habár a gyakorlatban mindkét fél tartotta magát a keretszámokhoz). Azóta azonban Moszkva nyíltan megsértette az Ukrajna területi integritását garantáló Budapesti Memorandumot, szintén megsértette a Nyitott Égbolt Szerződést és az Európai Hagyományos Fegyveres Erőkről szóló Szerződést, amely 2015-re teljesen összeomlott. A NATO szempontjából jelentős fegyverzetkorlátozási rendszer négy lábából (hagyományos, rakétavédelem, taktikai atomfegyverek és stratégiai atomfegyverek) gyakorlatilag elvesztettünk hármat. Az utolsó elem a 2021-ben lejáró Új START-szerződés. A sorozatos szerződésszegések tükrében az amerikai Kongresszus nem valószínü, hogy könnyedén jóváhagyna bármilyen új megállapodást, a Trump-kormány pedig egyelőre nem mutatott komolyabb érdeklődést a szerződés meghosszabbítására. Ezeknek az ellenőrző rezsimeknek a bukása egy egyébként is kiélezett NATO-orosz kapcsolatrendszerben tovább fokozza a kiszámíthatatlanságot, a véletlenszerü balesetek esélyét, s egy nem szándékolt eszkaláció lehetőségét. A felek bármikor is jussanak el újra a „Reagan-Gorbacsov felismerésig”, az biztos, hogy a tárgyalások következő köre jóval öszszetettebb lesz, mint az 1980-as években tárgyalt megállapodások voltak. Egyrészt valószínủ, hogy az amerikai-orosz bilaterális folyamatnak vége, és a jövőben elkerülhetetlen lesz Kína bevonása. Másrészt az is valószínű, hogy a mindössze egy fegyvernemet érintő szerződések ideje lejárt, és bármilyen nukleáris fegyverek korlátozását célzó megállapodásnak magában kell foglalnia a ballisztikus rakétavédelem, és talán még a modern hiperszonikus fegyverrendszerek kérdését is.

\section{FELHASZNÁLT IRODALOM}

BARrIE, Douglas - Boyd, Henry: Russian cruise missile goes off-range, [online], 2014. 07. 21. Forrás: IISS Military Balance Blog [2019. 02. 02.]

Buzhinsky, Evgeny: Does the INF Treaty Have a Future? Security Index: A Russian Journal on International Security, 20. évf., 2014/2, 89-93. o. DOI: https://doi.org/10.1080/19934270.2014.985098

Department of the Navy: United States Navy Fact File MK 41-VLS, [online], 2016. 05. 09. Forrás: Navy.mil [2019. 02.02.]

INF Treaty: Treaty Between The United States Of America And The Union Of Soviet Socialist Republics On The Elimination Of Their Intermediate-Range And Shorter-Range Missiles (INF Treaty), [online], 1987. 12. 08. Forrás: State.gov [2019. 02. 02.]

Intermediate-Range Nuclear Forces [INF], [online], 2019. 02. 02. Forrás: Fas.org [2019. 02. 02.]

KeARn, David W.: Russian Missiles and the Growing Security Crisis in Europe, [online], 2014. 08. 28. Forrás: European Leadership Network [2019. 02. 02.] 
KüHN, Ulrich - PÉCzeli, Anna: Russia, NATO, and the INF Treaty, [online], Strategic Studies Quarterly, 11. évf., 2017/1, 66-99. o. [2019. 02. 02.]

Lewis, Jeffrey: Russia and the INF Treaty, [online], 2014. 04. 28. Forrás: Arms Control Wonk [2019. 02. 02.]

MacFarquhar, Neil: Russia Shows Off New Cruise Missile and Says It Abides by Landmark Treaty, [online], 2019. 01. 23. Forrás: The New York Times [2019. 02. 02.]

McKeon, Brian P.: Statement of Honorable Brian P. McKeon, Principal Deputy Under Secretary of Defense for Policy before the House Committee on Armed Sercives, Subcommittee on Strategic Forces and Committee on Foreign Affairs, Subcommittee on Terrorism, Nonproliferation, and Trade, [online], 2014. 12. 10. Forrás: House.gov [2019. 02. 02.]

US-Russia Diplomatic Controversy Surrounding INF Treaty Requires Dialogue - Analysis, [online], 2014. 08. 16. Forrás: Eurasia Review [2019. 02. 02.]

Pifer, Steven: RIP INF: The End of a Landmark Treaty, [online], 2018. 10. 29. Forrás: The National Interest [2019. 02. 02.]

Pompeo, Michael R.: Remarks by Secretary of State at NATO Headquarters, December 2018, [online], 2018. 12. 04. Forrás: State.gov [2019. 02. 02.]

Pomper, Miles A. - Murauskaite, Egle - Sokov, Nikolai N. - Varnum, Jessica C.: Ensuring Deterrence against Russia: The View from NATO’s Front-Line States, [online], 2015. 12. 01. Forrás: Nonproliferation. org [2019. 02. 02.]

European nuclear powers must intervene in INF Treaty situation, expert says, [online], 2019. 02. 01. Forrás: Tass.com [2019. 02. 02.]

SANGer, David E. - BroAd, William J.: U.S. to Tell Russia It Is Leaving Landmark I.N.F. Treaty, [online], 2018. 10. 19. Forrás: The New York Times [2019. 02. 02.]

SAnger, David E.: U.S. Suspends Nuclear Arms Control Treaty With Russia, [online], 2019. 02. 01. Forrás: The New York Times [2019. 02. 02.]

Tiмoshiк, Alexander: New Russian missile R-500 to destroy any US defense system, [online], 2007. 05. 30. Forrás: Pravda [2019. 02. 02.]

U.S. Department of Defense: Nuclear Posture Review, [online], 2018. 02. 28. Forrás: Dod.defense.gov [2019. 02. 02.]

U.S. Department of State: Adherence to and Compliance With Arms Control, Nonproliferation, and Disarmament Agreements and Commitments, [online], 2014. 07. 31., 8. o. Forrás: State.gov [2019. 02. 02.]

Woolf, Amy F.: Russian Compliance with the Intermediate Range Nuclear Forces (INF) Treaty: Background and Issues for Congress, [online], 2015. 10. 13. Forrás: Congressional Research Service [2019. 02. 02.] 